\title{
The effects of the heat treatment on the microstructure of Inconel 625/steel bimetal joint obtained by explosive welding
}

\author{
R. Kosturek ${ }^{1, a}$, M. Wachowski ${ }^{1}$, L. Śnieżek ${ }^{1}$, M. Gloc ${ }^{2}$, U. Sobczak ${ }^{3,1}$ \\ ${ }^{1}$ Military University of Technology, Faculty of Mechanical Engineering, 2 gen. W. Urbanowicza Str., 00-908 Warsaw, Poland \\ ${ }^{2}$ Warsaw University of Technology, Faculty of Materials Science and Engineering, 141 Woloska Str., 02-507 Warsaw, Poland \\ ${ }^{3}$ The Building Research Institute, 1 Filtrowa Str., 00-611 Warsaw, Poland
}

\begin{abstract}
In this investigation steel P355NH was successfully clad with Inconel 625 through the method of explosive welding. Explosively welded bimetal was subjected to the two separated heat treatment processes: stress relief annealing (at $620^{\circ} \mathrm{C}$ for 90 minutes) and normalizing (at $910^{\circ} \mathrm{C}$ for 30 minutes). In order to identify the microstructure of the joint and to investigate the influence of the heat treatment on it, the light and scanning electron microscope observations and microhardness analysis have been performed. In order to investigate the diffusion zone microstructure the scanning transmission electron microscope observation have been performed. It was stated that obtained joint has characteristic wavy-shape geometry with the presence of the melted zones and severe deformed grains of both joined materials. Strengthening of materials in joint zone was established with microhardness analysis. In both of the heat treatments the changes in the grain structure have been observed. The normalizing heat treatment has the most significant impact on the microstructure of the joint as well as the concentration of the chemical elements in the joint zone. It was reported that due to normalizing the diffusion zone has been formed together with precipitates in the joint zone.
\end{abstract}

\section{Introduction}

Corrosive wear represents a significant problem for the utilization of components of equipment operating in an aggressive environment, such as equipment for the chemical industry and geothermal power plants $[1,2]$. The use of corrosion resistant alloys for the manufacture of components of equipment subject to wear is generally associated with considerable costs. An economical solution is to use clad materials where relatively inexpensive material, such as carbon steel, is covered by a layer of material that will provide protection from corrosion, e.g. acid resistant steel, which significantly reduces the costs of material used for the production of the equipment [3-5]. The present paper investigates steel P355NH clad with Inconel 625 as bimetallic material of the above type. Steel P355NH, unalloyed weldable constructional steel of fine grain structure, is used as material for the manufacture of pressure equipment operating under high temperature (up to $450^{\circ} \mathrm{C}$ ) [6]. Since this steel is not corrosion resistant, its life cycle during operation in an aggressive environment may be prolonged by cladding it with a layer of Inconel 625, hightemperature creep resistant alloy of nickel and chromium with an additive of molybdenum and niobium that is characterised by high resistance to oxidizing and reduction environment as well as pitting and crevice corrosion and it also displays tolerance to a wide range of operating temperatures (from $-150^{\circ} \mathrm{C}$ to $982^{\circ} \mathrm{C}$ ) [7]. The manufacturing of clad material in which steel $\mathrm{P} 355 \mathrm{NH}$ plays the load-bearing role and a layer of Inconel 625 alloy provides protection from corrosion may be achieved through explosive welding [8-11]. In the process, the energy released during detonation of the explosive is used for high velocity collision of metal materials [12-17]. The result of this high energy collision is bringing the surfaces of the welded materials close enough to each other to obtain interaction between their atoms and the consequent formation of a metallic bond between them $[14,18-20]$. The considerable plastic deformation of the materials, produced as part of the process, significantly influences the structure of the materials and strengthens the joint by plastic deformation. Clad materials manufactured using this method are subjected to further technological processes to form specific equipment components for the industry, e.g. tube plates for heat exchangers and converter bottoms. In order to decrease the degree of hardening of the materials and reduce the residual stresses, the materials are subjected to heat treatment [21-23]. The annealing of bimetallic materials leads to significant structural changes within the joint, which may deteriorate the mechanical properties [24]. Steel clad with Inconel 625 using explosive welding has been the subject of numerous studies, which have confirmed that it is possible to obtain such a bimetallic joint through explosive welding [8-11]. However,

\footnotetext{
${ }^{\mathrm{a}}$ Corresponding author: robert.kosturek@wat.edu.pl
} 
literature does not contain sufficient investigation of the effect of heat treatment on structural changes in the joint. According to previous studies by the authors of this paper, normalizing of Inconel 625 - steel P355NH joint obtained by explosive welding deteriorates its resistance to shear by $33 \%$ (decrease from $572 \mathrm{MPa}$ to $383 \mathrm{MPa}$, determined according to PN-EN13445:2014) [22]. The present paper aims to investigate the causes of such a drastic reduction in the resistance of the joint. Structural changes may involve both evolution of the grainy structure of the materials and diffusive transformations within the joint [21, 25-28]. Depending on the mutual solubility of the diffusing chemical elements of the alloy, brittle intermetallic compounds or new solid solutions may form in the joint area [29, 30]. The Kirkendall effect may accompany the diffusion changes, which consists in development of voids in the joint area due to differences in diffusion rates of individual alloying elements of the welded materials [25, 27, 31-33]. Additionally, Inconel alloys display a tendency to form precipitates (e.g. carbides, $\gamma^{\prime}, \gamma^{\prime \prime}$ and $\delta$ phases) upon long-term exposure to high temperature [34-37]. Importantly, plastic deformation of Inconel alloys exerts a considerable impact on the kinetics of precipitate formation, as it promotes their quicker development [38-40]. A factor promoting formation of carbides is heat treatmentinduced diffusion of carbon from the steel to the Inconel alloy, which contains elements showing considerable affinity to carbon $(\mathrm{Cr}, \mathrm{Mo}, \mathrm{Nb})$ [41]. For this reason, the layer of Inconel 625 alloy in the area of the joint produced through explosive welding is a zone prone to potential formation of precipitates during heat treatment of the bimetal.

\section{Experimental procedure}

The materials used in the study included a sheet of steel P355NH of $5 \mathrm{~mm}$ thickness and a sheet of Inconel 625 alloy of $3 \mathrm{~mm}$ thickness. The chemical composition of the materials is presented in Table 1 (Table 1). Samples were cut out of the sheets to investigate the microstructure of the materials at baseline, at the aswelded state. The process of explosive welding of steel P355NH and Inconel 625 alloy was performed by EXPLOMET High-Energy Techniques Works company. The explosive was modified ammonium nitrate/fuel oil (ANFO), with detonation velocity of $2700 \mathrm{~m} / \mathrm{s}$, determined using optical fibre sensors. Three samples were cut out of the bimetallic sheet produced by explosive welding, as shown on Fig. 1. One of the samples was subjected to heat treatment of stress relief annealing (at $620^{\circ} \mathrm{C}$ for 90 minutes), and another to normalizing (at $910^{\circ} \mathrm{C}$ for 30 minutes). The parameters of the heat treatment procedures were selected by EXPLOMET company based on their many years of experience in heat treatment of clad materials. As a result, three samples were obtained: a sample after explosive welding, one after stress relief annealing and one after normalizing (Table 2).

Table 1. Chemical composition of the alloys to be joined.

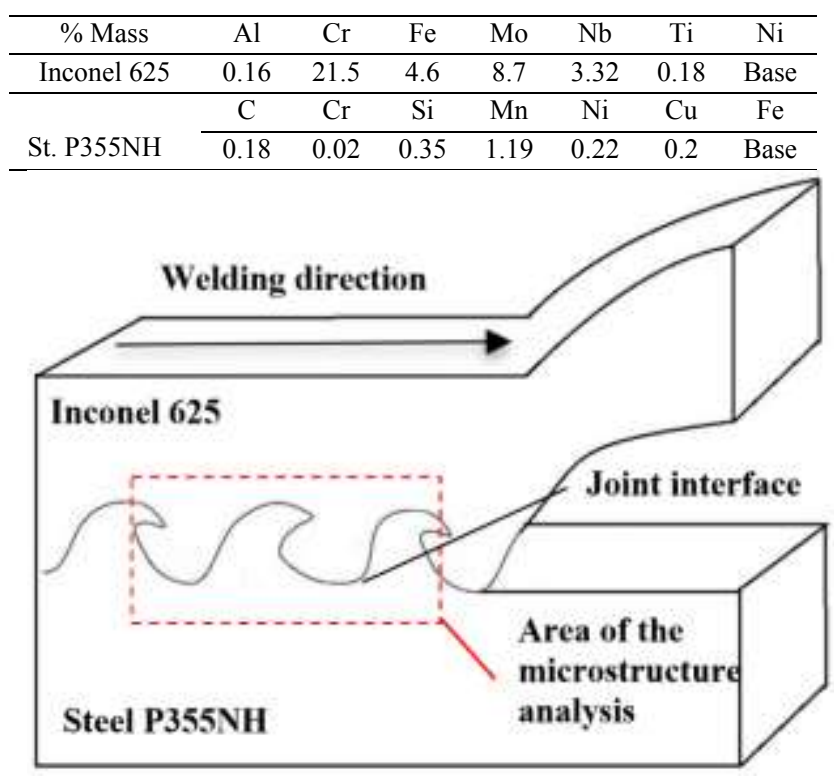

Figure 1. Area from which samples of bimetallic sheet were collected for microstructure investigation

Table 2. Samples designation.

\begin{tabular}{|c|c|}
\hline Shortcut & Description \\
\hline InSt EXW & $\begin{array}{c}\text { Bimetallic joint Inconel 625/steel P355NH } \\
\text { in the as-welded state }\end{array}$ \\
\hline InSt HTR & $\begin{array}{c}\text { Bimetallic joint Inconel } 625 / \text { steel P355NH } \\
\text { after stress-relief annealing }\left(620^{\circ} \mathrm{C} /\right. \\
90 \mathrm{~min})\end{array}$ \\
\hline InSt HTN & $\begin{array}{c}\text { Bimetallic joint Inconel } 625 / \mathrm{steel} \mathrm{P355NH} \\
\text { after normalizing }\left(910^{\circ} \mathrm{C} / 30 \mathrm{~min}\right)\end{array}$ \\
\hline
\end{tabular}

The samples were mounted in resin, grinded with abrasive paper of 80, 320, 600, 1200 and 2400 gradations and polished using diamond paste of $1 \mu \mathrm{m}$ gradation. To reveal the microstructure of steel $\mathrm{P} 355 \mathrm{NH}, 2 \%$ nital with etching time of 5-10 seconds was used and for Inconel 625 alloy, acetic glyceregia $(15 \mathrm{ml} \mathrm{HCl} \mathrm{38 \% ,10} \mathrm{ml}$ of acetic acid $99 \%, 5 \mathrm{ml} \mathrm{HNO}_{3} 65 \%, 1-2$ drops of glycerol) with etching time of 15 minutes. The microstructure of the samples was investigated using light microscope LEXT OLS 4100 and scanning electron microscope Joel JSM 6610. Additionally, an analysis of the microstructure of the joint zone was performed in the sample InSt HTN using scanning transmission electron microscope (STEM) Hitachi S-5500N. The samples for STEM were prepared using Dual beam system Hitachi NB-5000. The Vickers microhardness test was performed with loading of $100 \mathrm{~g}$. Microhardness distributions were prepared for each sample. The first two measurements were performed 200 $\mu \mathrm{m}$ from the joint line, in the layer of Inconel 625 alloy and in steel P355NH. Subsequently, measurement imprints were guided towards the edge of the samples, at the distance of $2000 \mu \mathrm{m}$.

\section{Results}

\subsection{Microstructure of the raw materials}

Microstructures of steel P355NH (Fig. 2a) and Inconel 625 alloy (Fig. 2b) in the as-welded state are presented on 
Fig. 2. Steel P355NH shows ferrite-pearlite structure with banded distribution of the pearlite, typical of sheets after rolling. According to the measurements, it is characterised by the presence of fine equiaxial grains sized $15.5 \pm 4.1 \mu \mathrm{m}$, specific to steel after normalizing. The microstructure of Inconel 625 alloy is more heterogen sous, with visible twins and grains sized $49.4 \pm$ $15.6 \mu \mathrm{m}$. 'The measurement outcomes for microhardness in the as-welded state were 249.6 $\pm 16.3 \mathrm{HV} 0.1$ for Inconel 625 alloy and 150.6 $\pm 4.9 \mathrm{HV} 0.1$ for steel $\mathrm{P} 355 \mathrm{NH}$, respectively.
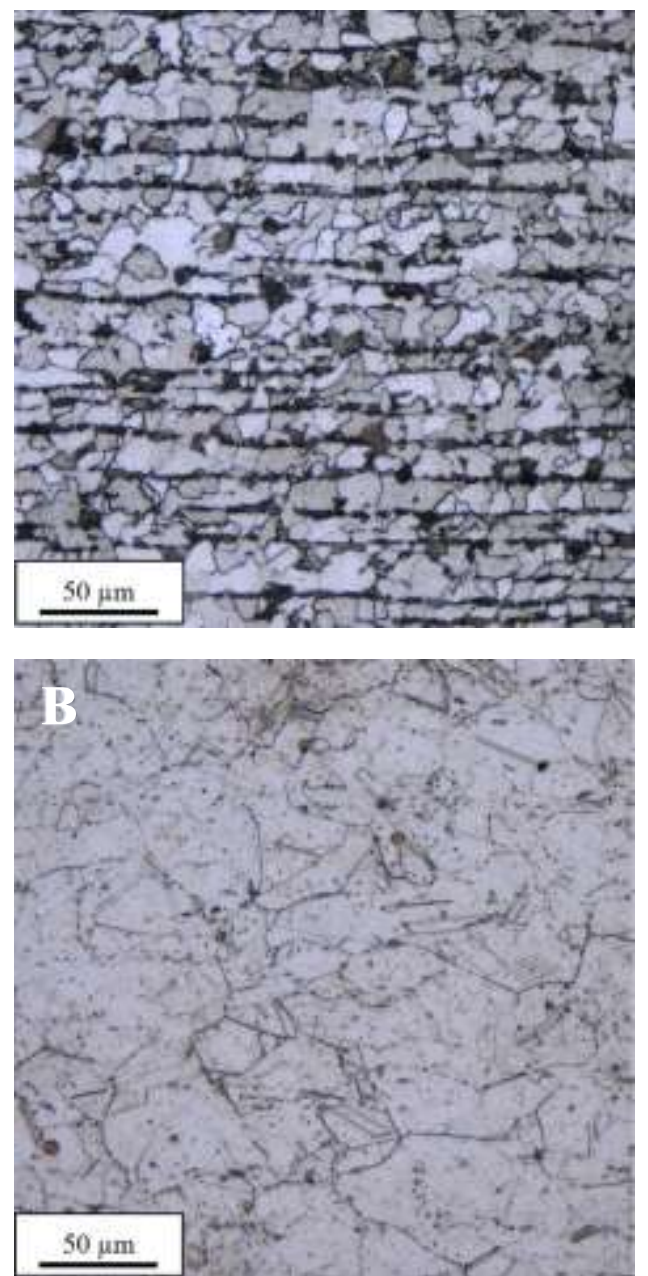

Figure 2. Microstructure of materials in the as-welded state a) steel P355NH b) Inconel 625.

\subsection{Microstructure of InSt EXW joint}

The joint produced by explosive welding displays a characteristic wavy geometry. The grains in the joint zone have undergone strong plastic deformation and have been observed to wrap to areas of intersurface waves in the samples after etching of steel P355NH (Fig. 3a) and Inconel 625 alloy (Fig. 3b).
A
Inconel 625
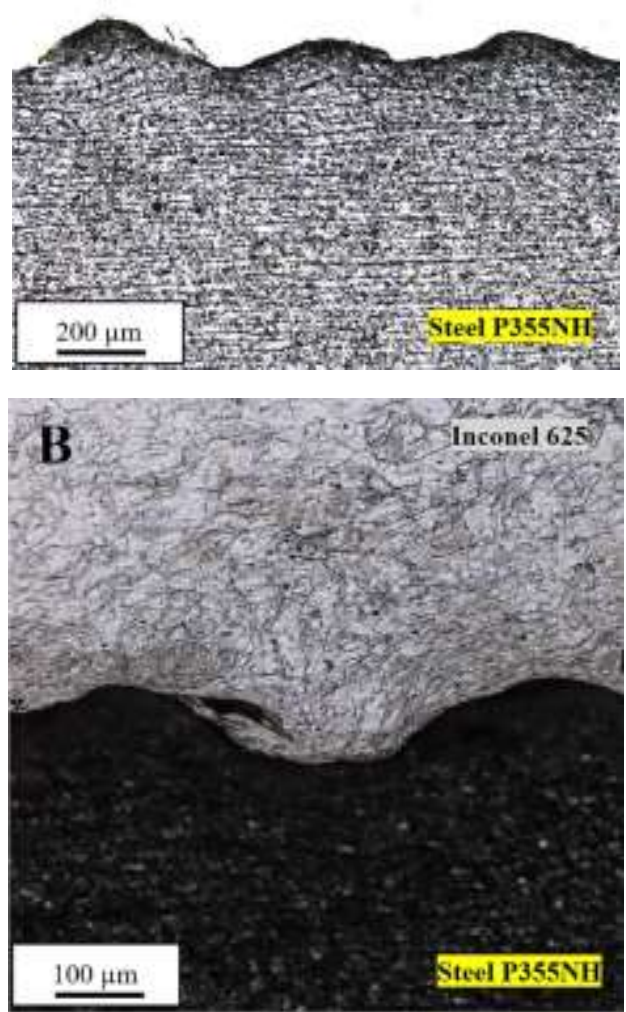

Figure 3. Microstructure of the joint in InSt EXW sample a) after etching of steel P355NH b) after etching of Inconel 625 alloy.

Additionally, fine, dynamically recrystallised grains of 1-2 $\mu \mathrm{m}$ size were found in steel $\mathrm{P} 355 \mathrm{NH}$ close to the joint line (Fig. 4). The observation using scanning electron microscope showed melted zones, where the two welded materials blended (Fig. 5a). In the melted zones, the investigation revealed the presence of joint imperfections in the form of cracks and fragments of the surface layer of steel $\mathrm{P} 355 \mathrm{NH}$, which underwent partial fragmentation during welding, as evidenced by linear analysis of the chemical composition (Fig. 5b) and analysis of iron (Fig. 5c) and nickel (Fig. 5d) distribution at the sample surface (mapping). 
Inconel 625

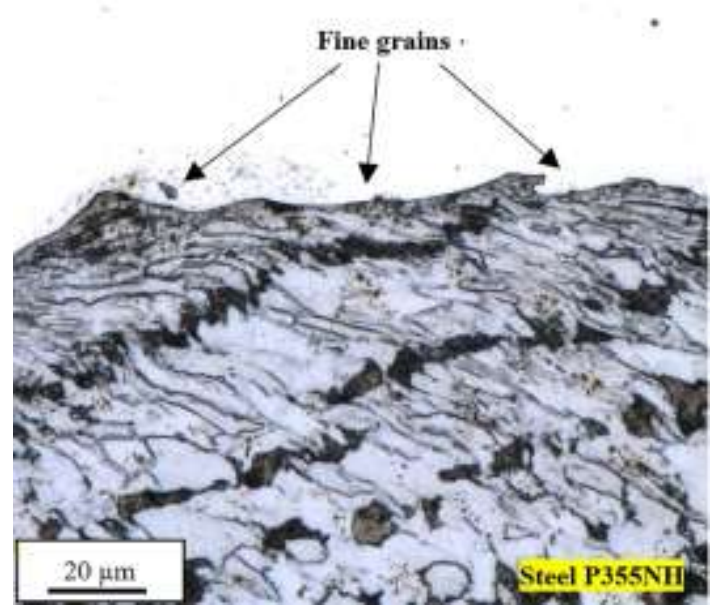

Figure 4. Fine grain structure of steel $\mathrm{P} 355 \mathrm{NH}$ in the joint area.
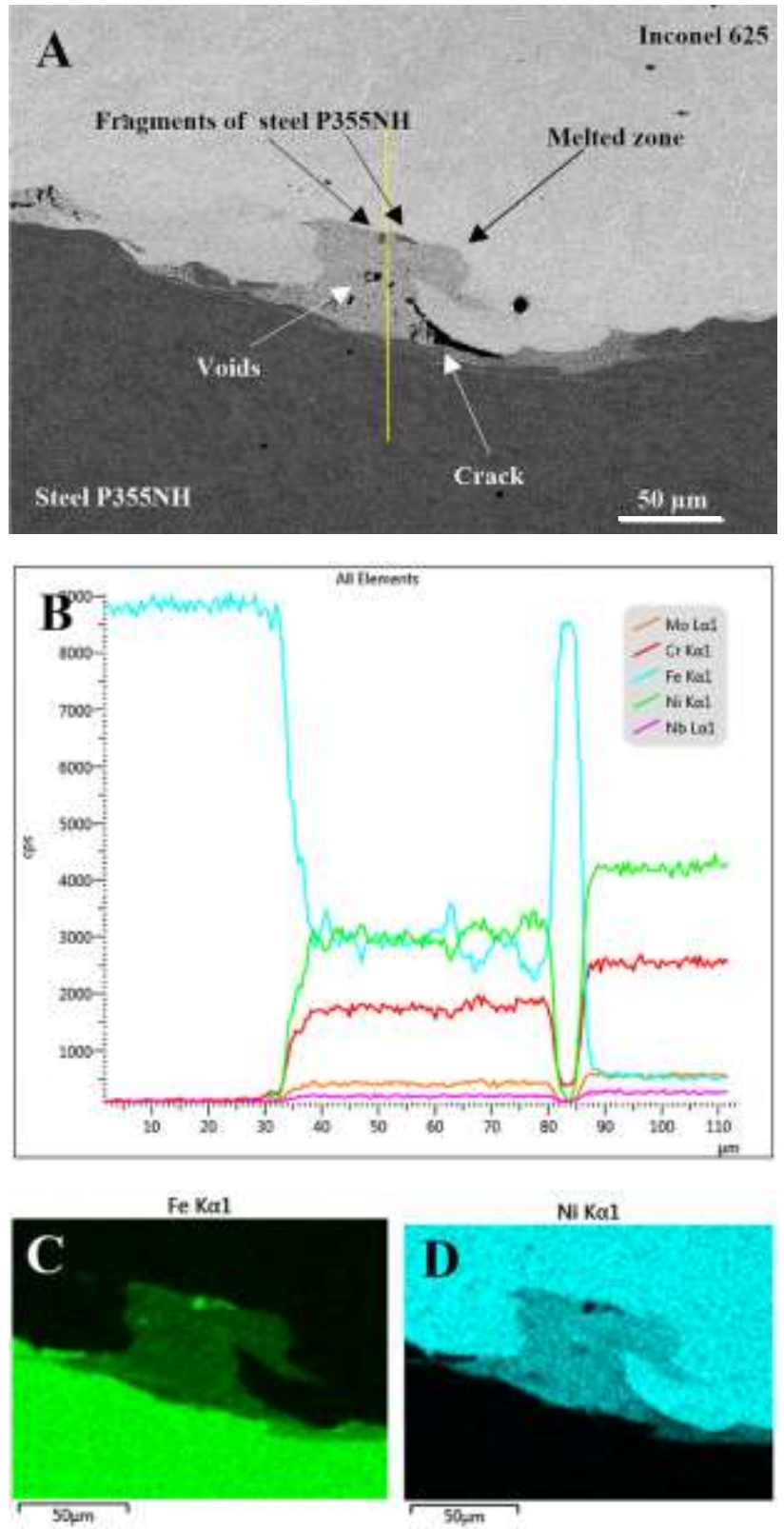

Figure 5. Melted zone in InSt EXW sample (a) with linear analysis of the chemical composition (b) (yellow marker) and mapping of iron (c) and nickel (d).

\subsection{Microstructure of InSt HTR joint}

Stress relief annealing, performed at $620^{\circ} \mathrm{C}$ for 90 minutes, led to partial recrystallisation of steel $\mathrm{P} 355 \mathrm{NH}$ grains in the area of $20-30 \mu \mathrm{m}$ from the joint, while the deformation texture of the material farther from the joint has been maintained (Fig. 6a). Observations of the microstructure of Inconel 625 alloy did not reveal visible changes in the grain morphology (Fig. 6b). Similarly, analysis of images from the scanning electron microscope did not show any visible changes in the concentration of alloying elements in the joint (Fig. 7).
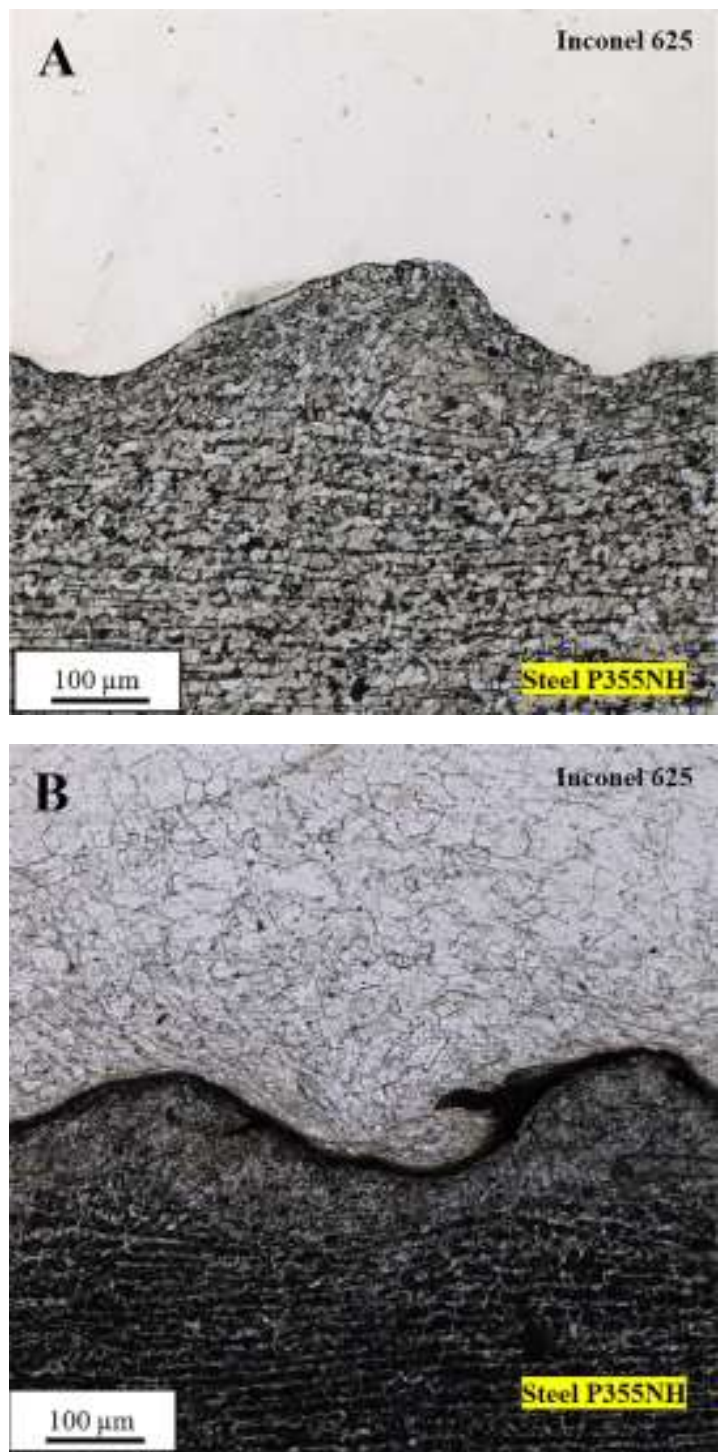

Figure 6. Microstructure of the joint in InSt HTR sample a) after etching of steel P355NH b) after etching of Inconel 625 alloy. 


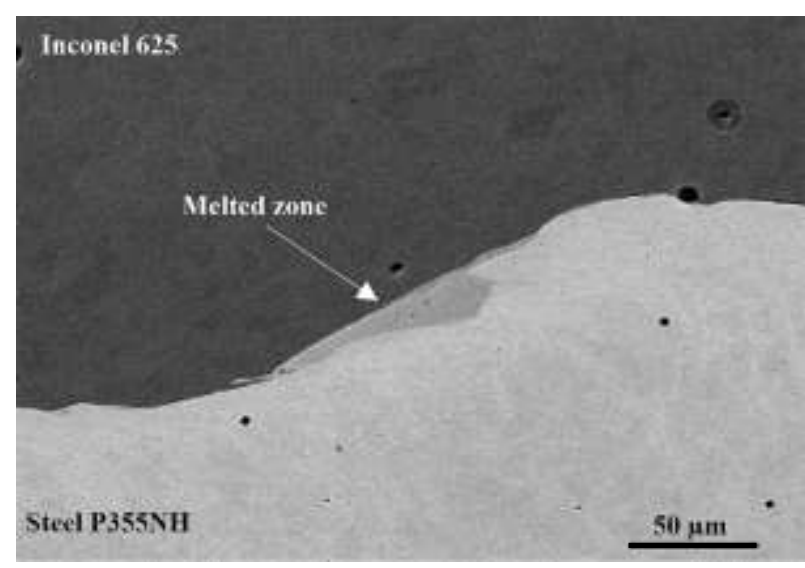

Figure 7. Image of the joint in InSt HTR sample from the scanning electron microscope.

\subsection{Microstructure of InSt HTN joint}

The microstructure of the joint subjected to normalizing at $910^{\circ} \mathrm{C}$ for 30 minutes changed considerably. Complete recrystallisation of the grainy structure of steel $\mathrm{P} 355 \mathrm{NH}$ (Fig. 8a) and Inconel 625 (Fig. 8b) alloy was revealed, manifested by disappearing of the deformation texture and the presence of fine equiaxial grains in the joint. The observation using scanning electron microscope showed considerable changes in the concentration of alloying elements in the joint area. Alloying elements of Inconel 625 were found to diffuse into steel $\mathrm{P} 355 \mathrm{NH}$ approximately $20 \mu \mathrm{m}$-deep and precipitates, located mainly in the joint area, were revealed in Inconel 625 alloy (Fig. 9a). Diffusion of iron from steel P355NH into Inconel 625 alloy was found up to $5 \mu \mathrm{m}$ deep. In the Inconel 625 alloy, light precipitates were revealed, suggesting a high concentration of alloying elements heavier than nickel, and dark precipitates, characterised by a high concentration of alloying elements lighter than nickel. Additionally, voids were found in the diffusion area (Fig 9b). The results of an analysis of alloying elements distribution on the surface of the sample in the joint area indicate an increased concentration of chromium in dark precipitates (Fig. 10b) and an elevated concentration of molybdenum in light precipitates (Fig. 10c). The results of nickel (Fig. 10a) and iron (Fig. 10d) distributions in the joint allow to observe a diffusion zone.
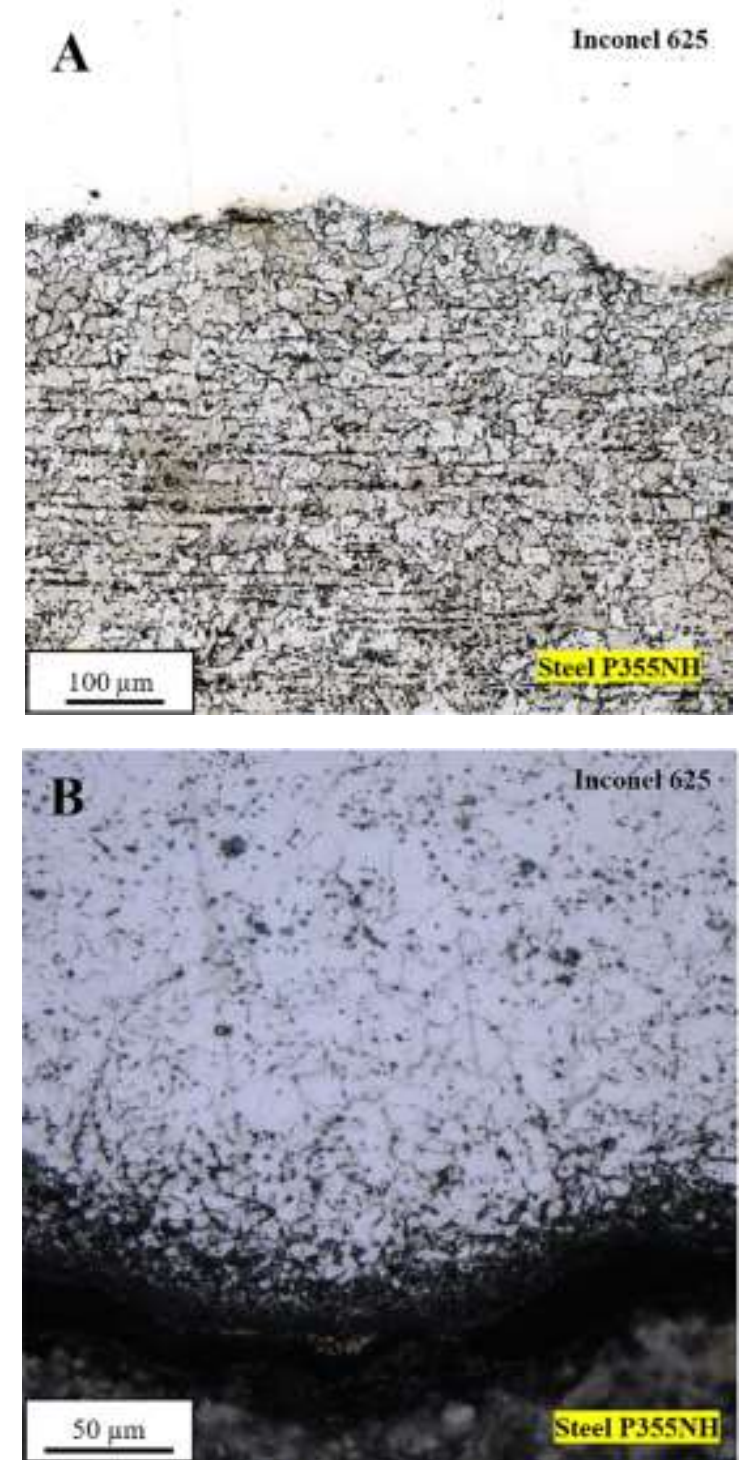

Figure 8. Microstructure of the joint in InSt HTN sample a) after etching of steel P355NH b) after etching of Inconel 625 alloy

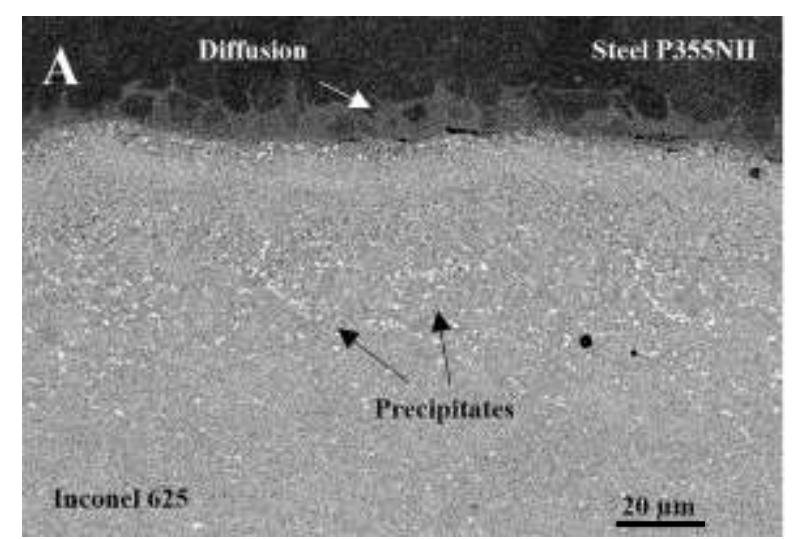




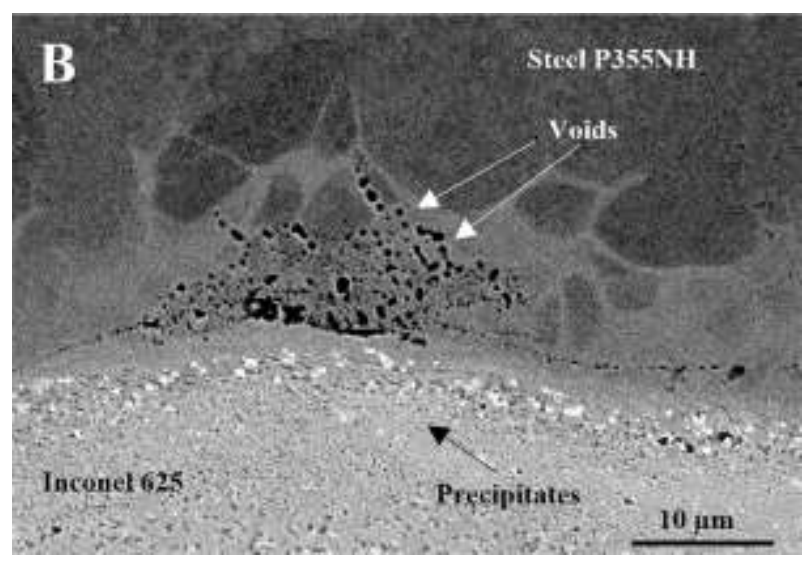

Figure 9. Image of the joint in InSt HTN sample from the scanning electron microscope a) precipitates in Inconel 625 alloy, b) diffusion zone
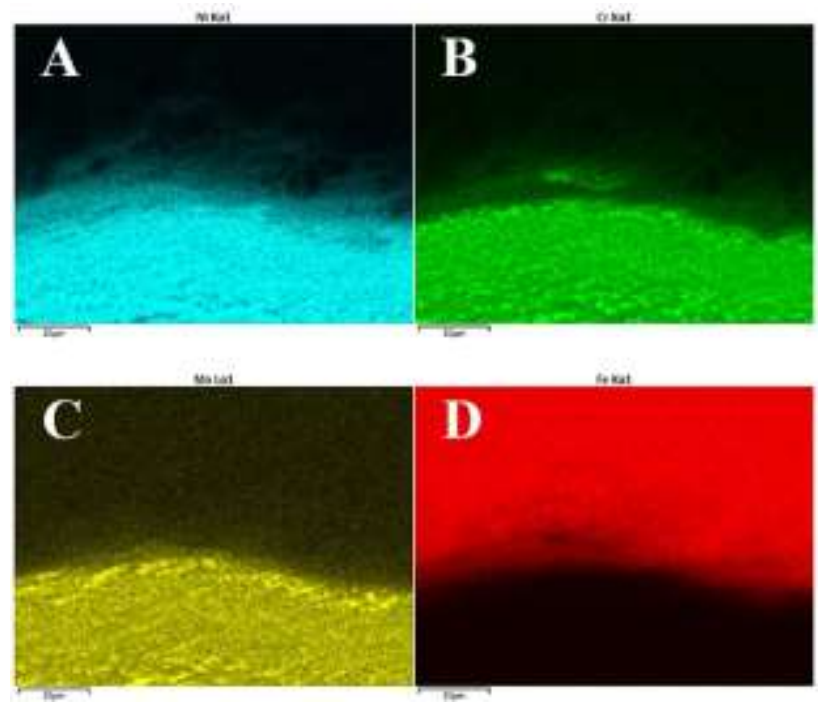

Figure 10. Distribution of alloying elements on the surface of InSt HTN sample in the joint area: a) nickel, b) chromium, c) molybdenum and d) iron.

\subsection{Scanning transmission electron microscope observations of the diffusion zone}

Observations of the diffusion zone performed on scanning transmission electron microscope indicates that this area consists of equiaxed grains (from side of Inconel 625 alloy) and columnar grains (from side of steel P355NH) (Fig. 11).

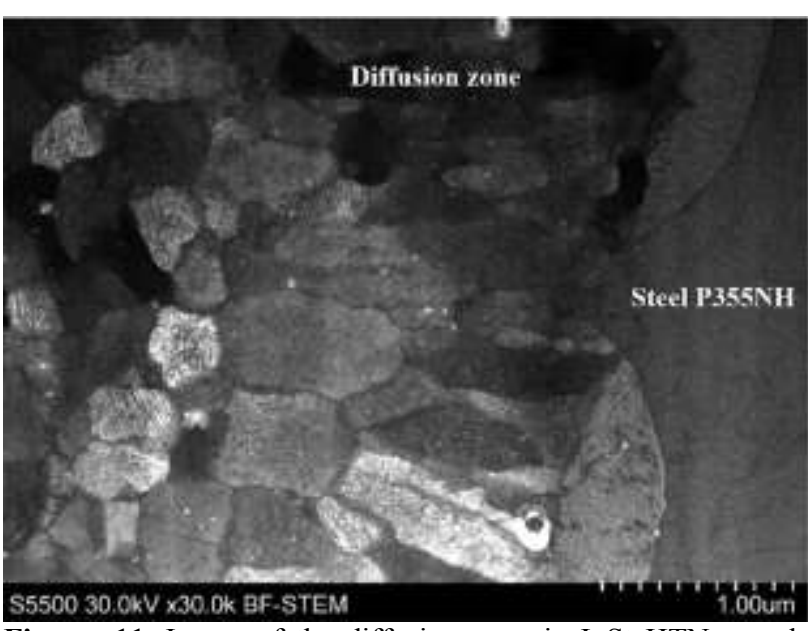

Figure. 11. Image of the diffusion zone in InSt HTN sample from the scanning transmission electron microscope.

Additionally, it has been reported the occurrence of precipitates with their width about $50 \mathrm{~nm}$ in the diffusion zone (Fig. 12).

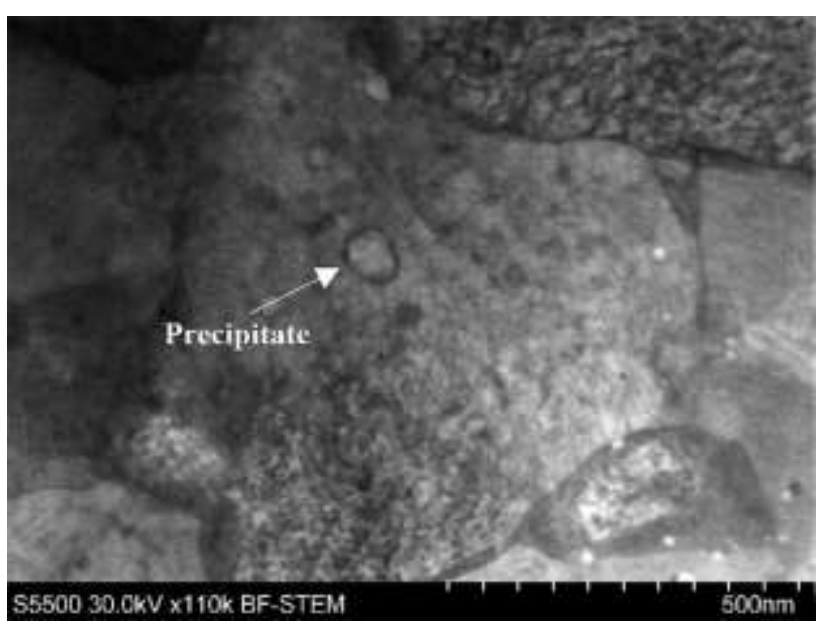

Figure. 12. Image of the precipitate in the diffusion zone from the scanning transmission electron microscope.

The results of linear analysis of the chemical composition of columnar grains (Fig. 13) and the precipitate (Fig. 14) in the diffusion zone are shown below.
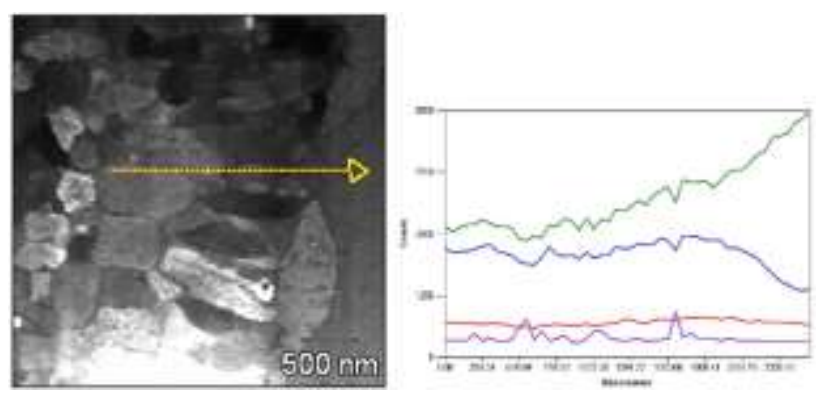

Figure. 13. The results of linear analysis of the chemical composition of columnar grains in the diffusion zone. Lines designation: $\mathrm{Fe}$ (green), $\mathrm{Ni}$ (blue), $\mathrm{Cr}$ (red), $\mathrm{Nb}$ (purple). 

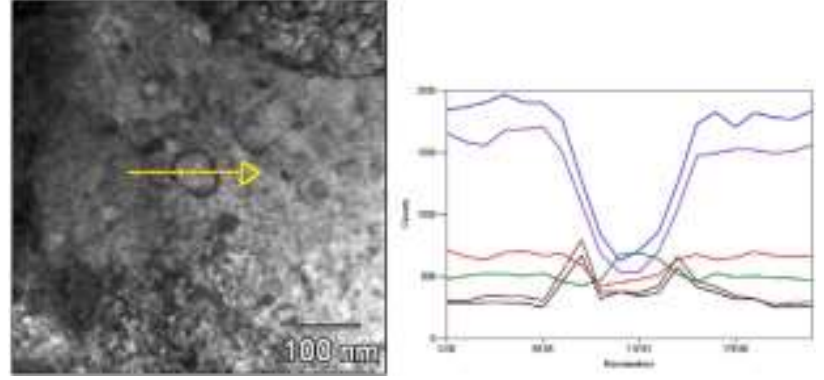

Figure. 14. The results of linear analysis of the precipitate in the diffusion zone. Lines designation: Fe (blue), Ni (purple), $\mathrm{Cr}$ (green), $\mathrm{Nb}$ (black), Mo (burgundy).

\subsection{Microhardness analysis}

The distributions of microhardness, prepared as part of the investigation, enable characterizing the degree of hardening of welded materials. The highest degree of hardening was revealed at the joint line, where materials underwent the strongest deformation. In Inconel 625 alloy, microhardness increased by ca. $200 \mathrm{HV}$ and in steel P355NH by ca. $100 \mathrm{HV}$. A noteworthy finding is that hardening of steel $\mathrm{P} 355 \mathrm{NH}$ in the joint shows a homogeneous nature, while in Inconel 625 alloy microhardness decreased with increasing distance from the joint. Stress relief annealing reduced the microhardness of steel P355NH by ca. $40 \mathrm{HV}$ due to recrystallisation of grains and led to a monotonic decrease in the microhardness of Inconel 625 alloy. Heat treatment in the form of normalizing reduced the microhardness of steel $\mathrm{P} 355 \mathrm{NH}$ to its baseline value, recorded before explosive welding.

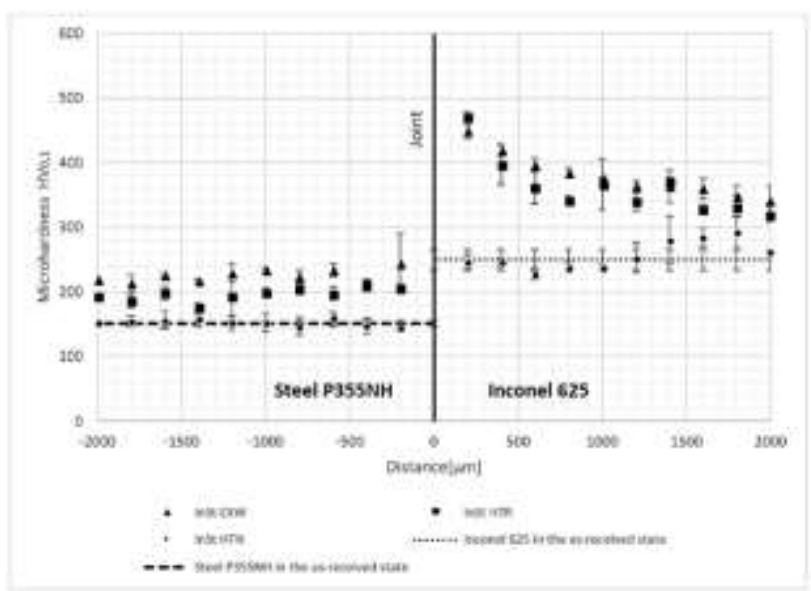

Figure 15. The results of microhardness analysis.

\section{Discussion}

The technique of explosive welding has produced a good quality joint between steel P355NH and Inconel 625 alloy, with characteristic wavy geometry and small amount of imperfections in the form of cracks, pores and melted zones. The melted zones have been found to display an evenly distributed blending of the welded materials, an increased concentration of imperfections and presence of fragments of steel P355NH surface layer. Light microscope observation of the bimetal microstructure after etching of steel P355NH and Inconel 625 alloy has revealed strong hardening of the materials in the joint area. Elongated compressed grains wrapping into intersurface waves have been found. Plastic deformation of the welded materials has been also reflected in the results of microhardness analysis, which suggests considerable hardening of steel P355NH and Inconel 625 alloy in the joint area. The microstructure of steel P355NH has shown fine, dynamically recrystallized grains close to the joint line. Heat treatment, both in the form of stress relief annealing and normalizing, has resulted in recrystallisation of steel $\mathrm{P} 355 \mathrm{NH}$ grains in the joint area. The steel grains are finest at the joint line, which indicates cumulation of the strongest deformation in this area due to interaction of the welded materials. This finding is further confirmed by the analysis of heatactivated phenomena as a function of the temperatures used for heat treatment. As a result of stress relief annealing at $620^{\circ} \mathrm{C}$, recrystallisation was found only in the joint area, while the banded grainy structure of the steel at a distance of ca. $100 \mu \mathrm{m}$ from the joint continued to show the original banded morphology. On the other hand, an increase of annealing temperature to $910^{\circ} \mathrm{C}$ results in a complete restructure of the grainy structure of steel P355NH, which had been defected through plastic deformation. It is a well known fact that the higher degree of plastic deformation, the lower energy is necessary to trigger and complete heat-activated phenomena and therefore the recrystallisation temperature is lower, which explains the incomplete restructure of the deformed steel structure after stress relief annealing. Changes in the concentration of alloying elements in the joint area after heat treatment in the form of normalizing are manifested through formation of both a diffusion zone and precipitates in Inconel 625 alloy. An analysis of images of the diffusion zone by scanning electron microscope leads to the conclusion that the diffusion of alloying elements of Inconel 625 alloy into steel P355NH takes place along the grain boundaries. Moreover, voids have been found in the diffusion zone, which are most probably due to the Kirkendall effect. An analysis of the phase equilibrium of iron-nickel may suggest that the diffusion zone is composed predominantly of nickel austenite $\gamma$ and a small amount of nickel ferrite $\alpha$ (Fig.16).

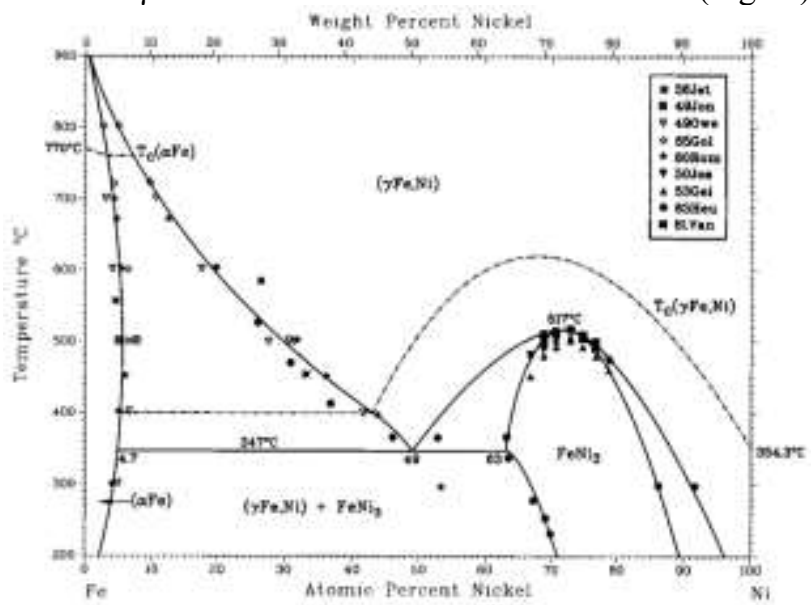

Figure 16. Graph of phase equilibrium for iron - nickel [42]. 
Precipitates due to normalizing in Inconel 625 alloy are located along the grain boundaries and twins, which has been revealed based on comparison of images of the sample after etching from the scanning electron microscope and light microscope. An analysis of an isothermal transformation diagram for Inconel 625 alloy leads to the conclusion that the parameters of the normalizing used are close to the area of carbide formation, mainly of $\mathrm{MC}$ and $\mathrm{M}_{6} \mathrm{C}$ type (Fig. 17).

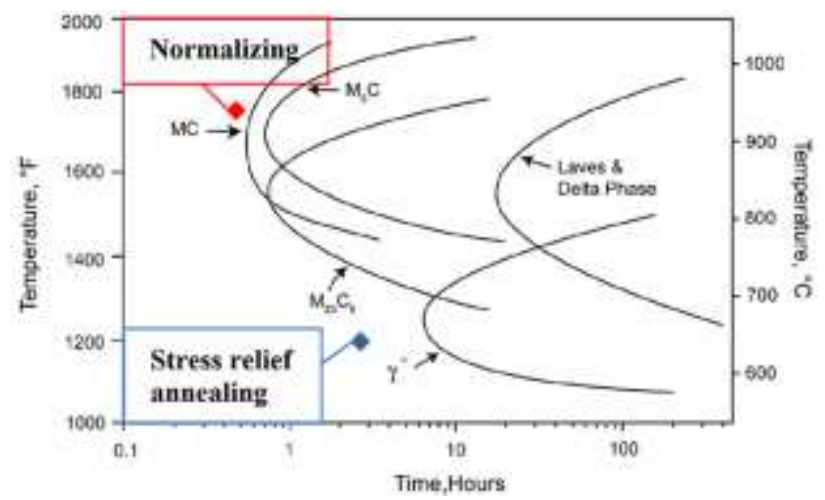

Figure 17. Isothermal transformation diagram for Inconel 625 alloy [35]. Values of stress relief annealing and normalizing have been marked

A noteworthy fact is that the strong plastic deformation of Inconel 625 alloy in the joint reduced the energy of heat-activated processes, including precipitate processes. An additional factor promoting formation of carbides is diffusion of alloying elements of steel P355NH into Inconel 625 alloy (in particular carbon, whose content in the steel is $0.18 \%$ ). An analysis of distribution of alloying elements on the surface of the sample and microstructure observations using the scanning electron microscope enabled identifying two basic types of precipitates: light precipitates, rich in molybdenum, and dark precipitates, rich in chromium. Literature on diffusion in the bimetallic configuration of Inconel 625 alloy and low-alloyed steel precisely describes the precipitates as carbides of $\mathrm{M}_{6} \mathrm{C}$ type in the case of high molybdenum content and of $\mathrm{M}_{23} \mathrm{C}_{6}$ type in the case of high chromium content [41]. The structural analysis of samples after normalizing indicates that both the diffusion zone and precipitates in Inconel 625 alloy represent the causes of deteriorated endurance of the joint compared to the as-welded state. In the diffusion zone, not only voids have been found, but also the structure itself, which contains soft nickel ferrite $\alpha$ on the side of steel P355NH and resistant nickel austenite $\gamma$ on the side of Inconel 625 alloy, significantly deteriorates the quality of the joint. Carbides, forming along the grain boundaries and twins in Inconel 625 alloy, also reduce the coherence of the material in the most crucial zone, i.e. the joint. The results of scanning transmission electron microscope observations of the diffusion zone, allow to investigate the microstructure of the diffusion zone, which consist of equiaxed and columnar grains. The precipitates in the diffusion zone are chromium-rich, surrounded by area of high concentration of niobium and molybdenum.
The process of explosive welding using ammonium nitrate $(\mathrm{V})$ as the explosive, with detonation speed of ca. $2700 \mathrm{~m} / \mathrm{s}$ enabled obtaining joint between steel P355NH and Inconel 625 alloy. The joint was found to include precipitate zones with an increased concentration of imperfections in the form of cracks, voids and fragments of the surface layer of steel P355NH. Stress relief annealing $\left(620^{\circ} \mathrm{C} / 90 \mathrm{~min}\right)$ led to partial recrystallization of steel P355NH in the joint area. Heat treatment in the form of normalizing $\left(910^{\circ} \mathrm{C} / 30 \mathrm{~min}\right)$ resulted in complete recrystallization of both welded materials, which was additionally confirmed by distributions of microhardness. Moreover, a diffusion zone of ca. $20 \mu \mathrm{m}$ thickness formed in the joint and precipitates in the form of carbides of $\mathrm{M}_{6} \mathrm{C}$ and $\mathrm{M}_{23} \mathrm{C}_{6}$ types appeared in Inconel 625 alloy. The presence of the chromium-rich precipitates have been stated in the diffusion zone.

\section{Acknowledgements}

This work uses results of the research from the project MEra.net "Novel explosive welded corrosion resistant clad materials for geothermal plants", co-financed from The National Centre for Research and Development of Poland (No DZP/M-ERA.NET-2013/2309/2014). This work was also supported by the university grant RMN 725/2017.

\section{References}

1. S.N. Karlsdóttir, S.M. Hjaltason, K.R. Ragnarsdóttir, Geothermics 70, 222-229 (2017)

2. G. V. Tomarov, A. A. Shipkov, Thermal Engineering 53, 188-194 (2006)

3. K. Yang-Hyun, Y. Jae Ho, P. Jeong-Yong, K. KeonSik, K. Hyun-Gil, K. Dong-Joo, J. Yang-Il, S. KunWoo, Nuclear technology 186, 295-304 (2014)

4. A. Strasser, J. Santucci, K. Lindquist, W. Yario, G. Stern, L. Goldstein, L. Joseph, Evaluation of stainless steel cladding for use in current design LWRs. Final report (Electric Power Research Institute EPRI NP, 1982)

5. W. Bristowe, M. Pearson, C. Stunguris, S. Gothard, Titanium 2010 - Proceedings of the 26th Annual Conference of the International Titanium Association (2010)

6. EN 10216-3:2002: Seamless steel tubes for pressure purposes. Technical delivery conditions. Alloy fine grain steel tubes.

7. J. C. M. Farrer, The Alloy Tree: A Guide to LowAlloy Steels, Stainless Steels, and Nickel-base Alloys (Woodhead Publishing, 2004)

8. H. R. Z. Rajani, S. A. A. A. Mousavia, Combustion, Explosion, and Shock Waves 49, 2 (2013)

9. H. R. Z. Rajani, S. A. A. A. Mousavia, Journal of Failure Analysis and Prevention 12, 6 (2012)

10. H. R. Z. Rajani, S. A. A. A. Mousavia, Materials Science and Engineering 556 (2012).

11. H. R. Z. Rajani, S. A. A. A. Mousavia, Materials and Design 43 (2013)

\section{Conclusions}


12. W. Walczak, Zgrzewanie wybuchowe metali, (Wydawnictwa Naukowo-Techniczne, Warsaw, Poland, 1989)

13. T. Z. Blazynski, Applied Science (1983)

14. W. Babul, S. Ziemba, Materiaty wybuchowe w technologicznych procesach obróbki tworzyw, (Państwowe Wydawnictwo Naukowe, Warsaw, Poland, 1972)

15. W. Babul, Odksztatcanie metali wybuchem, (Wydawnictwa Naukowo-Techniczne, Warsaw, Poland, 1980)

16. H. Dyja, A. Maranda, R. Trębiński, Zastosowania technologii wybuchowych w inzynierii materiałowej, (Wydawnictwo Wydziału Metalurgii i Inżynierii Materiałowej Politechniki Częstochowskiej, Częstochowa, Poland, 2001)

17. T. Babul, P. Oleszczak, Inżynieria materiałowa 31, 4 (2010)

18. F. Findik, Materials and Design 32 (2011)

19. A. Ambroziak, Zgrzewanie tarciowe materiałów o różnych właściwościach, (Oficyna Wydawnicza Politechniki Wrocławskiej, Wrocław, Poland 2011)

20. K. Topolski, P. Wieciński, Z. Szulc, A. Gałka, H. Grabacz, Materials and Design 63 (2014)

21. T. N. Prasanthi, C. Sudha, R. Kirana, S. Saibaba, Materials and Design 93, 180-193 (2016)

22. R. Kosturek, M. Najwer, P. Nieslony, M. Wachowski, Advances in Manufacturing, Lecture Notes in Mechanical Engineering book series, 681-686 (2018)

23. A. Pocica, R. Bański, P. Waindok, Z. Szulc, A. Gałka XVI International Conference ,Spawanie $w$ energetyce”, Poland (2008)

24. H. Jian, X. Yan, J. Liu, X. Duan, Transactions of Nonferrous Metals Society of China 24, 697-704 (2014)

25. S.A.A. Akbari Mousavi, P. Farhadi Sartangi, Materials Science and Engineering: A 494, 329-336 (2008)

26. L. F. Trueb, Metallurgical Transactions 2, 145-153, (1971)

27. J. Maliutina, V. Mali, A. K. Skorokhod, A. Bataev, Applied Mechanics and Materials 698, 495-500 (2015)

28. F. Findik, R. Yilmaz, T. Somyurek, Scientific Research and Essays 6, 4141-4151 (2011)

29. D.M. Fronczek, R. Chulist, L. Litynska-Dobrzynska, S. Kac, N. Schell, Z. Kania, Z. Szulc,J. WojewodaBudka, Materials \& Design 130, 120-130 (2017)

30. D.M. Fronczek, R. Chulist, Z. Szulc, J. WojewodaBudka, Materials Letters 198, 160-163 (2017)

31. X. Wang, X. Li, F. Yan, C. Wang, Welding in the World 61, 187-196 (2017)

32. C. Chen, H. Chen, W. Hwang, Materials Transactions 47, 1232-1239 (2006)

33. M. Mazar Atabaki, M. Nikodinovski, P. Chenier, J. Ma, M. Harooni, R. Kovacevic, Journal for Manufacturing Science and Production 14, 59-78.

34. P. Petrzak, K. Kowalski, M. Blicharski, Acta Physica Polonica A 130, 4 (2016)

35. L.E. Shoemaker, The Minerals, Metals \& Materials Society (2005)
36. A. Sukumaran, R.K. Gupta, V. Anil Kumar, Journal of Materials Engineering and Performance (2017)

37. P. Maj, B. Adamczyk-Cieslak, M. Slesik, J. Mizera, T. Pieja, J. Sieniawski, T. Gancarczyk, S. Dudek, Archives of Metallurgy and Materials 62, 1695-1702.

38. L. Rongbin, Y. Mei, L. Wenchang, H. Xianchang, Journal of Materials Engineering and Performance, Volume 11 (2002)

39. W. C. Liu, F. R. Xiao, M. Yao, H. Yuan, Z. L. Chen, Z. Q. Jiang, S. G. Wang, W. H. Li, Journal of Materials Science Letters 17, 245-247 (1998)

40. M. Yunpeng, L. Yongchang, L. Chenxi, L. Chong, Y. Liming, G. Qianying, L. Huijun, Journal of Alloys and Compounds 649, 949-960 (2015)

41. B. López, I. Gutiérrez, J.J. Urcola, Diffusion Bonding 2, 37-48 (1991)

42. J. L. Swartzendruber, Journal of Phase Equilibria 12 (1991) 